\title{
RESULTS OF MONITORING OF NATURAL AND ANTHROPOGENIC AGRO ECOSYSTEMS TRANSFORMATION IN THE VORONEZH REGION FOR THE PERIOD OF AGRICULTURAL ENVIRONMENTAL MANAGEMENT
}

(C) 2020

\author{
Almobarak Falak, postgraduate student of Geography and Tourism Department \\ Mezhova Lydia Aleksandrovna, candidate of geographical sciences, \\ associate professor of Geography and Tourism Department \\ Voronezh State Pedagogical University (Voronezh, Russian Federation)
}

\begin{abstract}
The paper deals with the theoretical analysis of peculiarities of agricultural nature management influence on the components of natural environment in the Voronezh Region. A retrospective analysis of soil research reveals a degree of its degradation. Dynamics of agro ecosystems development and the degree of change in the natural background of vegetation are determined; the peculiarities of agricultural impact are shown. The value of land resources in the Voronezh Region is determined by their fertility. The State Center of Agrochemical Service «Voronezh» and the State Station of Agrochemical Service «Talovskaya» control the structure, dynamics and condition of soils. As a result, soils of agro ecosystems on phosphorus, potassium, humus, acidity, heavy metals, mineral fertilizers and pesticides are comprehensively monitored. The Land Committee for the Voronezh Region reveals violations of the land legislation. Agro ecosystems have an unclosed cycle of biogenic elements. This is related to the loss of nutrients during harvesting and the activation of erosion processes. Changes in the balance of basic soil nutrients reduce the quality and yield of crops. Agro ecological monitoring includes systematic observation, study and analysis. In this regard, there is a need for research into the significant magnitude of the associated factors. The existing system of regional monitoring is based on the repeatability of soil, agrochemical and bacteriological studies of agroecosystems. Both continuous and local agro monitoring is conducted. It should be noted that agroecosystems of the region are insufficiently provided with biogenic elements, microelements and in this connection there is a need to create a model of balanced agricultural environmental management.

Keywords: ingredients; pesticides; monitoring; transformation; natural-anthropogenic processes; soil erosion; microelements; crop yields; agroecological monitoring; mineral fertilizers; humus; fertility.
\end{abstract}

\section{БИОРАЗНООБРАЗИЕ ОСОБО ОХРАНЯЕМОЙ ПРИРОДНОЙ ТЕРРИТОРИИ ИВАНОВСКОЙ ОБЛАСТИ «ОЗЕРО ЧЕРНОЕ (ТАКОВЕЦ)»}

(C) 2020

Борисова Елена Анатольевна, доктор биологических наук, профессор, заведующий кафедрой общей биологии и физиологии

Курганов Антон Александрович, кандидат биологических наук, доцент кафедры общей биологии и физиологии

Лазарева Ольга Германовна, заведующий учебной лабораторией кафедры общей биологии и физиологии Ивановский государственный университет (2. Иваново, Российская Федерация)

Марков Дмитрий Сергеевич, кандидат географических наук, доцент кафедры истории, географии и экологии

Шуйский филиал Ивановского государственного университета (2. Шуя, Ивановская область, Российская Федерация)

Аннотаиия. В статье обсуждаются вопросы особо охраняемых природных территорий (ООПТ) местного значения. Озеро Черное, или Таковец, расположено в Лежневском муниципальном районе Ивановской области, получило статус ООПТ в 1975 г., в 2001 г. отнесено к ООПТ местного значения. Площадь акватории озера составляет 10,8 га, площадь ООПТ - 17 га. Приводятся данные комплексного экологического обследования данного озера: кратко охарактеризованы параметры озера, рельеф берегов и почвы, особенности флоры, растительности, животного мира. Флора отличается богатством: к 2019 г. отмечено 256 видов сосудистых растений, относящихся к 5 отделам, 6 классам, 62 семействам, 164 родам. 13 видов растений относятся к редким для флоры Ивановской области, среди них 3 вида (Nuphar pumila, Rubus chamaemorus, Rubus nessensis) включены в региональную Красную книгу, описано состояние их популяций. Разнообразен видовой состав мхов (всего отмечено 29 видов). Фауна типична для небольших закрытых озер региона. Озеро испытывает значительный антропогенный пресс, его экосистемы нарушены, что способствует внедрению многих заносных видов (всего было отмечено 28 чужеродных видов растений). Озеро имеет большое гидрологическое, средообразующее и природоохранное значение, перспективно для развития экологического и событийного туризма.

Ключевые слова: особо охраняемые природные территории (ООПТ); озера; батиметрическая схема; растительные сообщества; флора; популяции редких видов растений; заносные и инвазионные виды растений; виды мхов; особенности фауны; Красная книга; Лежневский район; Ивановская область. 

Биоразнообразие особо охраняемой природной территории Ивановской области..

\section{Введение}

В соответствии с федеральным природоохранным законодательством особо охраняемым природным территориям местного значения отводится важная роль. В Ивановской области к категориям ООПТ местного значения отнесены только 2: охраняемый природный комплекс и туристско-рекреационная местность (Закон Ивановской области от 06.05.2011 г. № 39-O3).

Изучение ООПТ регионального и местного значения проводится в области, начиная с 2012 г. Обследованы ООПТ Верхнеландеховского [1], Ильинского [2; 3], Комсомольского [4; 5], Пестяковского [6], Южского [7; 8] и других муниципальных районов.

Лежневский район расположен на юго-западе Ивановской области, его общая площадь составляет 772,5 км$^{2}$, около $60 \%$ территории занимают леса. По территории района протекает 11 рек, самыми крупными из которых являются Уводь и ее притоки Ухтохма и Вязьма, имеется 4 озера (Селецкое, Красный Остров, Черное, или Таковец, и Козино), несколько крупных болот, сохранились старинные усадебные парки (парк в с. Чернцы, парк в д. Жидково).

При обследовании района в 1990-х г М.П. Шиловым было предложено 11 ценных объектов [9]. Озера Красный Остров и Селецкое имеют статус памятников природы регионального значения, 12 природных объектов признаны ООПТ местного значения, среди них и озеро Черное, или Таковец.

Озеро Черное, или Таковец, находится в 14 км северо-западнее пос. Лежнево, в 3 км юго-западнее с. Чернцы, в 0,7 км юго-восточнее д. Аладино, в 1 км северо-восточнее д. Таковец. Это озеро признано памятником природы в 1975 г. (Решение исполнительного комитета Ивановского областного Совета народных депутатов от 27.01.1975 г. № 2/6), позднее этот статус был подтвержден Решением Лежневского районного исполнительного комитета (от 27.12.1991 г. № 201), в 2001 г. оно отнесено к ООПТ местного значения.

Флора и растительность озера и его окрестностей изучались спорадически в 1990-е гг., в августе 2011 г. в рамках программы по ведению Красной книги на его берегах были отмечены некоторые редкие виды растений [10].

Однако специальных исследований этого озера не проводилось, отсутствовали сведения о границах ООПТ, сведения о растительном и животном мире, необходимые для составления паспорта.

Материалы и методы исследований

В июле-сентябре 2019 г. проведено комплексное экологическое исследование данного озера в рамках Муниципального контракта. Состав, структура флоры и растительности изучались маршрутным методом. Были описаны основные типы лесов, луговые сообщества, особенности водной и прибрежно-водной растительности. Наиболее интересные, а также сложные в таксономическом отношении виды растений собирались в гербарий. Гербарные образцы сосудистых растений будут переданы в гербарий им. Д.П. Сырейщикова (MW), гербарные образцы водных видов - в гербарий ИБВВ РАН (IBIW), гербарий мхов - в гербарий Плесского государственного музея-заповедника (PLES).

Измерения глубины озера по всей площади акватории проводились с использованием эхолота и GPSнавигатора. Цифровая модель рельефа дна озера Таковец была построена с применением ГИС технологий - ArcGIS 10 (ESRI) и Surfer (Golden Software). Латинские названия видов растений приводятся в соответствии с последней флористической сводкой по Средней России [11]. Исследование фауны проводилось в июле 2019 г., основное внимание уделялось насекомым и наземным позвоночным. Была оценена численность некоторых видов земноводных и пресмыкающихся

\section{Результаты исследований и их обсуждение}

Озеро Черное, или Таковец, находится в плоском депрессионном понижении рельефа. Средняя высота местности составляет 133 м над уровнем моря. Долина озера выражена слабо. По площади это очень небольшое (площадь акватории составляет 10,8 га) и глубокое (максимальная глубина озера в центре достигает 20,1 м) озеро. Вода в нем чистая, прозрачная, специальный анализ воды не проводился. Берега в основном низкие, торфянистые, заболоченные, только восточный берег открытый, песчаный. На дне много топляка из коряг и бревен.

На батиметрической схеме представлены особенности дна озера (см. рис. 1).

ООПТ относится к зоне дерново-подзолистых почв, южнотаежно-лесной подзоне, Среднерусской провинции дерново-подзолистых среднегумуссированных почв, плоскоравнинному среднезаболоченному песчаному и болотно-подзолистому округу, западному дерново-подзолистому и торфяно-болотному супесчаному и суглинистому почвенному району [12]. По данным описания почвенных профилей установлено, что по берегам озера распространены перегнойно-глеевые среднемощные, поверхностно оглеенные и торфяные среднемощные суглинистые почвы.

Растительность. Озеро практически со всех сторон окружено заболоченными лесами различного породного состава. Ниже приводятся описания основных типов лесов по берегам озера.

Сосново-березовые чернично-разнотравные леса. Древостой представлен сосной обыкновенной и березой повислой, единично встречаются осина, ель высокая. Отмечено присутствие старовозрастных сосен и берез (диаметр стволов 45-60 см), общая сомкнутость крон составляет 0,7. Подлесок выражен неравномерно, в нем встречаются рябина обыкновенная, крушина ломкая, малина лесная, реже - дуб черешчатый, липа сердцелистная, можжевельник обыкновенный. В травяно-кустарничковом ярусе преобладает черника, встречаются группы майника двулистного, брусники, осоки лесной, седмичника европейского, щитовника шартрского. Реже встречаются купальница европейская, ортилия однобокая, костяника, золотарник обыкновенный, земляника лесная, ожика волосистая, вероника лекарственная, воронец колосистый и др. Зеленые мхи обычны в основании стволов деревьев, на пнях, валежнике, спорадически группами встречаются сфагновые мхи. 


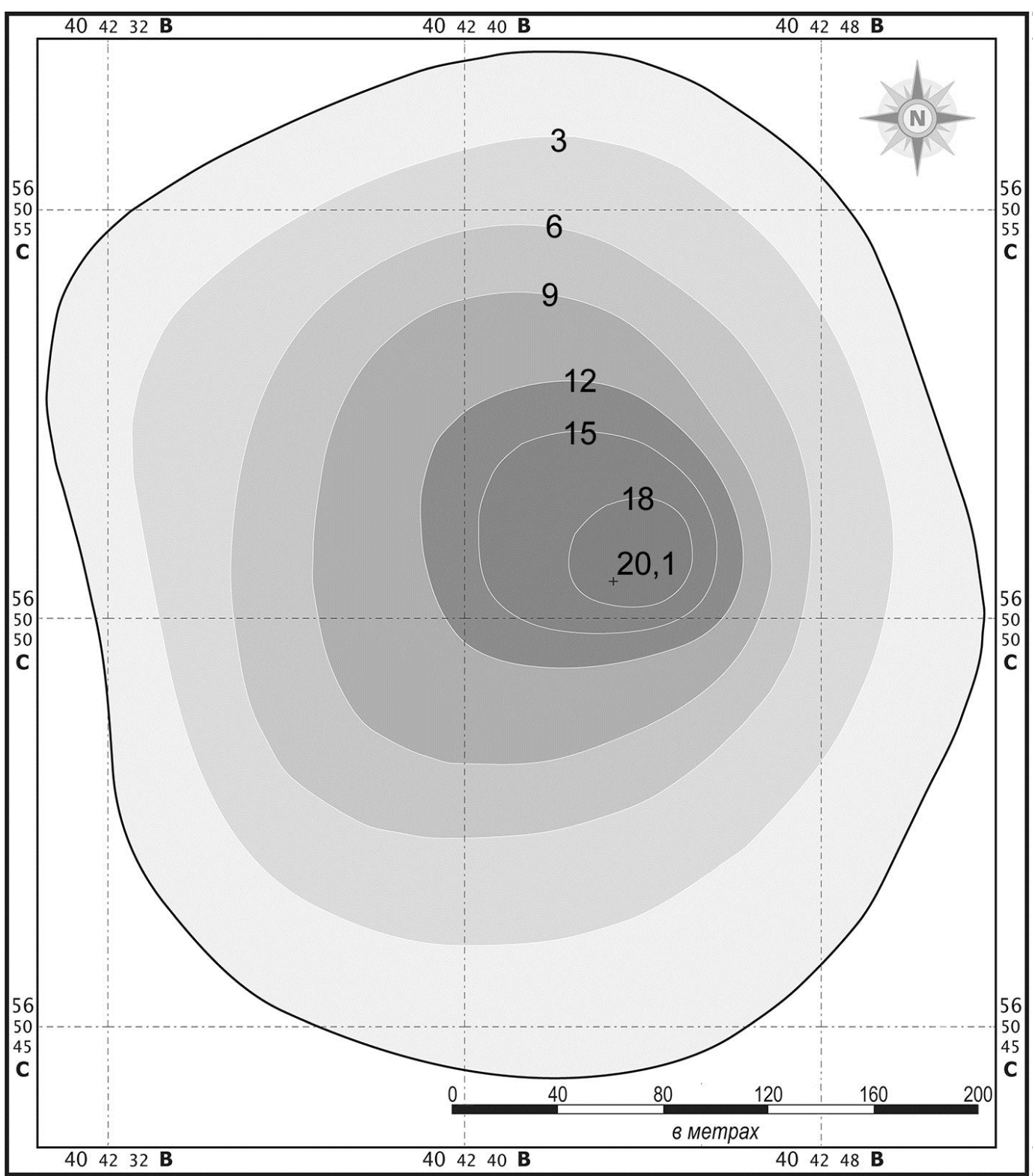

Рисунок 1 - Батиметрическая схема озера Черное, или Таковец

Сосняк с участием березы сфагново-брусничный. Древостой разрежен, сомкнутость крон составляет 0,5-0,6. Древостой формируют средневозрастные сосны (диаметр стволов 30-35 см), встречаются одиночные деревья березы и ели. Подлесок не выражен, встречаются группы молодых елей, крушина ломкая, рябина обыкновенная, можжевельник обыкновенный. В травяно-кустарничковом ярусе преобладает брусника, встречается черника, лапчатка прямостоячая, здесь отмечена крупная популяция морошки. Сфагновые мхи встречаются группами, у берега формируют сплошной покров.

Березняк с участием сосны черничный. В древостое преобладает береза пушистая, единично встречаются сосна обыкновенная, осина, ель высокая. Сомкнутость крон составляет 0,7-0,8. Подлесок выражен неравномерно, в нем встречаются крушина ломкая, рябина обыкновенная, калина, черемуха птичья, реже малина. В травяно-кустарничковом ярусе преобладает черника, формирующая крупные заросли, реже встречается брусника, кислица обыкновенная, щитовник шартрский, хвощ лесной, купальница европейская, пальчатокоренник Фукса, дудник лесной, крапива двудомная, марьянник дубравный, фиалка дубравная, земляника лесная, золотарник обыкновенный, осока удлиненная и др. Сфагновые и зеленые мхи встречаются группами.

Ельник кисличный. Участки ельников кисличных встречаются преимущественно на северо-восточном берегу озера. Древостой сформирован елью высокой (отмечены старовозрастные экземпляры), единично встречаются деревья осины и березы. Сомкнутость крон составляет 0,7-0,8. Подлесок не выражен, единично встречаются деревца рябины обыкновенной и осины в угнетенном состоянии. В травяно-кустарничковом ярусе отмечены группы кислицы обыкновенной, черники, одиночно встречаются щитовник шартрский, марьянник луговой, ожика волосистая, фиалка собачья, земляника лесная и др. Общее проективное покрытие составляет 10-25\%. Небольшими группами встречаются зеленые мхи.

Елово-березовый кислично-разнотравный лес. Древостой сформирован елью высокой и березой, формула древостоя - 7ЕЗБ. Подлесок выражен неравномерно, в нем присутствуют жимолость лесная, калина обыкновенная, крушина ломкая, малина лесная, 
рябина обыкновенная, редко - можжевельник обыкновенный, бузина раскидистая, единично - деревца липы мелколистной. В травяно-кустарничковом ярусе доминирует кислица обыкновенная, встречаются группы костяники, земляники лесной, осоки лесной, живучки ползучей, лютика золотистого, реже - щитовник мужской, грушанка круглолистная, кипрей горный, звездчатка жестколистная, мицелис стенной, марьянник дубравный и др. Зеленые мхи встречаются на пнях, валежнике, на стволах деревьев, реже на почве.

Черноольховник крупнотравный. Древостой сформирован ольхой черной, встречаются деревья осины и березы пушистой. Подлесок не выражен, в нем встречаются смородина черная, крушина ломкая, черемуха птичья, ива пепельная. В травяном ярусе преобладают группы крапивы двудомной, таволги вязолистной, белокрыльника болотного, телиптериса болотного, осоки удлиненной, вейника седеющего, реже - дудник лесной, щитовник шартрский, тиселинум болотный, дербенник иволистный, паслен сладко-горький и др. Отмечены крупные группы зеленых мхов.

Черноольховник с участием осины и березы пушистой травянистый описан на западном берегу озера. Древостой сформирован средневозрастными деревьями ольхи черной, встречаются группы молодых деревьев осины и березы пушистой. Сомкнутость крон составляет 0,7-0,8. Среди кустарников встречаются отдельные экземпляры аронии Мичурина, смородины черной. В травянистом ярусе отмечены группы папоротников - щитовников гребенчатого и шартрского, крапивы двудомной, таволги вязолистной, камыша лесного, в пониженных участках группы белокрыльника болотного, вахты трехлистной, дербенника иволистного, тесилинума болотного, вейника седеющего. Встречаются группы сфагновых мхов, на кочках - зеленые мхи.

Молодой густой осинник травянистый. Древостой формируют молодые осины (диаметр стволов 7-15 см), одиночно встречаются молодые деревца березы пушистой, ивы козьей, ольхи серой. Подлесок не выражен, присутствуют одиночные деревца рябины обыкновенной, ели высокой, поросль осины. В травяно-кустарничковом ярусе встречаются щитовник шартрский, хвощ лесной, осока шаровидная, марьянник луговой, крапива двудомная, земляника лесная, костяника, фиалка болотная и др. Общее проективное покрытие составляет 15-30\%. Группами встречаются зеленые и сфагновые мхи.

Луговая растительность. Сбитые суходольные луга встречаются на восточном берегу озера. Они представлены злаково-разнотравными сообществами. Среди злаков встречаются полевица тонкая, лисохвост луговой, щучка дернистая, пырей ползучий, ежа сборная, тимофеевка луговая, мятлик луговой. Из бобовых отмечены группы клеверов лугового и гибридного, горошка мышиного, чины луговой. Среди разнотравья на лугах обычны звездчатка злаковая, золотарник обыкновенный, василек луговой, зверобой пятнистый, подмаренник мягкий, лапчатки, сивец луговой, льнянка обыкновенная, лютик многоцветковый, тысячелистник обыкновенный и другие виды. В составе лугов встречаются многие сорные виды, например, ромашник непахучий, мелколепестник канадский, пикульник двураздельный, горошек узколистный, бодяк полевой, фиалка полевая, марь белая и др.

Водная растительность по обилию и флористическому составу бедная. В целом надводная растительность покрывает 1-3\% акватории озера, плавающая и погруженная - менее $1 \%$. Сообщества плавающих гидрофитов представлены кубышкой малой, стрелолистом обыкновенным, водокрасом лягушачим, ряской малой. Погруженная растительность представлена группами элодеи канадской.

На мелководьях отмечены плотно сомкнутые сообщества (проективное покрытие - более 70\%) с доминированием болотницы болотной и хвоща приречного с участием ежеголовника прямого, частухи подорожниковой, манника наплывающего, вероники щитковой, лютика жгучего и др. На отмелях распространены сильно разреженные (проективное покрытие - менее $10 \%$ ) сообщества из бутерлака портулакового, ситника членистого и лягушачьего, незабудки болотной и др.

Прибрежно-водная растительность. По берегам озера встречаются сообщества ольхи черной и березы белой с кустарниками (ива пепельная и ушастая, крушина ломкая, черемуха птичья и др.) травянистые. Редко крупные деревья сосен подходят к самому берегу озера.

Травяные сообщества по берегам озера отличаются разнообразием, различными сочетаниями таких доминантов, как телиптерис болотный, камыш лесной, тростник южный, щучка дернистая, осоки (пузырчатая, вздутая, удлиненная и др.). В них отмечаются молиния голубая, ситник развесистый, чистец болотный, сабельник болотный, реже - виды череды (трехраздельная, олиственная, поникшая), зюзник европейский, шлемник обыкновенный, рогоз широколистный, подмаренник болотный, вербейник обыкновенный и др. На западном и восточном берегах озера встречаются небольшие по площади монодоминантные сообщества из белокрыльника болотного, телиптериса болотного, вахты трехлистной.

Сорно-рудеральная растительность. По краям лугов, на нарушенных участках присутствуют бурьянистые заросли сорно-рудеральных растений (бодяк полевой, пижма обыкновенная, лопух паутинистый, цикорий обыкновенный, мелколепестник канадский и др.). Местами бодяк полевой и иван-чай узколистный формируют крупные заросли. На восточном берегу озера у дороги отмечены крупные группировки мари белой и ромашника непахучего. Группировки с доминированием сорно-рудеральных растений встречаются вдоль дороги, ведущей к озеру, а также в местах отдыха населения.

Флора. В результате проведенных исследований установлено, что во флоре озера и его окрестностей насчитывается 256 видов сосудистых растений, относящихся к 5 отделам, 6 классам, 62 семействам и 164 родам. Такое видовое богатство обусловлено значительным экотопологическим разнообразием. Основные параметры флоры ООПТ представлены в табл 1. 
Борисова Е.А., Курганов А.А., Лазарева О.Г., Марков Д.С.

Биоразнообразие особо охраняемой природной территории Ивановской области..

Общая биология

Таблица 1 - Основные параметры флоры ООПТ «Озеро Черное, или Таковец»

\begin{tabular}{|c|c|c|c|}
\hline $\begin{array}{c}\text { Название } \\
\text { таксона }\end{array}$ & $\begin{array}{l}\text { Число } \\
\text { видов }\end{array}$ & $\begin{array}{l}\text { Число } \\
\text { родов }\end{array}$ & $\begin{array}{c}\text { Число } \\
\text { семейств }\end{array}$ \\
\hline Polypodiophyta & 8 & 5 & 3 \\
\hline Equisetophyta & 3 & 1 & 1 \\
\hline Lycopodiophyta & 1 & 1 & 1 \\
\hline Pinophyta & 3 & 3 & 3 \\
\hline $\begin{array}{l}\text { Magnoliophyta, } \\
\text { в том числе: }\end{array}$ & 241 & 154 & 54 \\
\hline - Magnoliopsida & 183 & 124 & 43 \\
\hline - Liliopsida & 58 & 30 & 11 \\
\hline Всего & 256 & 164 & 62 \\
\hline
\end{tabular}

К числу ведущих семейств флоры ООПТ относятся сложноцветные (Compositae), представленные 35 видами, злаки (Gramineae) - 25 видами, розоцветные (Rosaceae) - 20 видами, осоковые (Cуperaceae) 15 видами; семейства гвоздичные (Caryophyllaceae) и норичниковые (Scrophulariaceae) содержат по 10 видов каждое. Вместе данные семейства охватывают почти половину $(44,9 \%)$ всего видового состава флоры. Данные семейства традиционно занимают ведущие позиции по числу видов, что характерно для среднерусской флоры. Крупными родами флоры ООПТ являются осока (Carex), представленная 13 видами, ситник (Juncus), лютик (Ranunculus) содержат по 6 видов, фиалка (Viola), кипрей (Epilobium), вероника (Veronica) - по 5 видов.

В результате флористических исследований на ООПТ обнаружены популяции 13 редких для флоры Ивановской области видов сосудистых растений. Ниже приводим краткую характеристику их местонахождений; виды, отмеченные знаком «*», включены в Красную книгу Ивановской области [13], остальные - в дополнительный список таксонов, нуждающихся в постоянном контроле популяций.

Cystopteris fragilis (L.) Bernh., несколько экземпляров найдено в сыром елово-березовом кисличноразнотравном лесу, в месте вывороченных с корнями елей.

Dryopteris expansa (C. Presl) Fraser-Jenkins et Germy, крупные одиночные экземпляры найдены в разреженном ельнике зеленомохово-кисличном с участием березы и осины.

Lycopodium annotinum L., встречается в сырых леcax северо-западного и северного берегов озера в густых кустарниковых зарослях, местами формирует плотные протяженные группы, обильно спороносит.

Juniperus communis L., изредка одиночные угнетённые, часто с желтой и бурой хвоей экземпляры встречаются в подлеске лесов по берегам озера.

Carex sylvatica Huds., группы вегетирующих и плодоносящих растений отмечены в сырых еловоберезово-сосновых лесах и на их опушках на южном и западном берегах озера, популяции крупные, устойчивые.

Carex globularis L., растет группами в заболоченных сосняках черничных на северо-западном берегу озера, формируя крупную популяцию.

Dactylorhyza fuchsii (Druce) Soo, в 2019 г. встречался редко единичными экземплярами в смешанных лесах и на их опушках. При исследовании берегов озера в 2011 г. вид был распространен шире, отмечался небольшими группами.
*Nuphar pumila (Timm.) DC., встречается одиночными экземплярами и небольшими группами на мелководьях практически по всей береговой полосе озера, генеративных экземпляров в 2019 г. не обнаружено. При исследовании озера в 2011 г. отмечались генеративные особи с бутонами и цветками. Интересен факт наличия по берегам озера многочисленных оторванных листовых пластинок и цветков данного растения. Популяция вида в озере угнетенная, о чем говорит отсутствие зарослей и развитых генеративных особей. Вид в Ивановской области находится под угрозой исчезновения и требует строгой охраны.

Trollius europaeus L., часто встречается в сырых лесах в понижениях и на опушках, группами и одиночно, особенно часто по западному берегу озера.

*Rubus chamaemorus L., только в 2019 г. большая популяция (площадь $30 \times 10$ м) была обнаружена на северо-западном берегу озера в редине средневозрастного сосняка с березой и елью и подлеском из крушины ломкой и рябины обыкновенной. Растения морошки были в угнетенном состоянии, без плодов, росли рыхлыми группами на лесной подстилке, а также в сфагновых мхах и в густых зарослях брусники.

*Rubus nessensis W. Hall, группа молодых побегов на площади $4 \times 2,5$ м найдена на западном берегу озера в сероольховнике с сосной в окружении Frangula alnus, Betula pendula и молодых сосен. Группы этого редкого вида также были отмечены по берегам озер Заборье и Поныхарь в Южском районе [8; 14]. В регионе встречается фрагментарно, преимущественно в южной части. Крупных зарослей не образует. В соседней Владимирской области этот вид относится к обычным растениям [15].

Centaurium erythraea Rafin, одиночные экземпляры встречены на низкотравном сыром лугу восточного берега, а также на опушке ельника северного берега озера.

Galium trifidum L., встречается по краям небольших сплавин и заболоченным берегам озера.

По берегам озера, кроме выше указанных, были отмечены и другие редкие, спорадически встречающиеся в регионе виды, например, Carex brunnescens (Pers.) Poir., C. echinata Murr., Juncus ambiguus Guss., Actaea spicata L., Lathyrus sylvestris L., Myosotis caespitosa K.F. Schultz, Mycelis muralis (L.) Dumort.

Богато представлены здесь моховидные, всего в составе бриофлоры ООПТ отмечено 29 видов мхов. Среди них 24 вида относятся к зеленым мхам (Amblystegium serpens (Hedw.) B.S.G., Atrichum undulatum (Hedw.) P. Beauv., Aulacomnium palustre (Hedw.) Schwägr., Brachythecium rivulare (Bruch) B.S.G., B. rutabulum (Hedw.) Schimp., B. salebrosum (Web. et Mohr) B.S.G., Callicladium haldanianum (Grev.) H.A. Crum., Calliergon cordifolium (Hedw.) Kindb., Calliergonella lindbergii (Mitt.) Hedenäs, Climacium dendroides (Hedw.) Weber et Mohr., Dicranum montanum Hedw., D. polysetum Sw., D. scoparium Hedw., Leptobrium pyriforme (Hedw.) Wils., Orthotrichum speciosum Nees, Plagiomnium cuspidatum (Hedw.) T.J. Kop., Pleurozium schreberi (Brid.) Mitt., Polytrichum juniperinum Hedw., Polytrichum commune Hedw., Ptilium crista-castrensis (Hedw.) De Not., Sanionia uncinata (Hedw.) Loeske, Sciuro-hypnum curtum (Lindb.) Ignatov, Stereodon pallescens (Hedw.) Mitt., Thuidium recognitum (Hedw.) Lindb.), 3 вида - к сфагновым 
мхам (Sphagnum capillifolium (Ehrh.) Hedw., Sph. girgensohnii Russ., Sph. squarrosum Crome) и 2 вида - к печеночным мхам (Ptilidium pulcherrimum (Weber) Hampe., встречается очень часто, особенно на валежных стволах и Riccia fluitans L., которая обнаружена на песчаных отмелях восточного берега озера). Редких видов моховидных не отмечено, но собранный материал мхов важен для уточнения распространения моховидных в регионе [16].

Фауна типична для небольших закрытых озер региона. Из насекомых наиболее характерны виды отрядов прямокрылые, равнокрылые хоботные, стрекозы, полужесткокрылые, жесткокрылые, чешуекрылые, перепончатокрылые и двукрылые. Численно преобладали в период обследования фауны бабочки белянки и бархатницы, кобылки, зеленчуки, цикадки, из жуков - мягкотелки, из двукрылых - настоящие комары и долгоножки, из перепончатокрылых - рыжий лесной муравей.

Большое видовое разнообразие характерно для чешуекрылых, жесткокрылых и двукрылых. Среди чешуекрылых наиболее разнообразны белянки и нимфалиды. Хорошо представлены пяденицы, совки, листовертки, огневки, толстоголовки, бархатницы. Украшением ООПТ являются крупные перламутровка большая лесная, перламутровка-адиппа, пестрокрыльница изменчивая, дневной павлиний глаз и другие бабочки, отмеченные на лугах восточного берега озера. Для луговой растительности и лесных опушек характерно разнообразие прямокрылых и цикадок. Много видов выявлено на цветущих луговых растениях (в том числе 3 вида шмелей). Отмечена вонючая (пятнистая) бронзовка (Oxythyrea funesta Poda). В последние годы ареал этого исконно лесостепного и степного вида значительно расширился на север.

Из жесткокрылых наиболее типичны семейства жужелицы, пластинчатоусые, листоеды (особенно листоед ясноточный, отмеченный на пикульнике), усачи, мягкотелки, малашки, короеды (березовый заболонник).

Молодые деревья ели по берегам озера часто повреждаются хермесами (Adelgidae). В кустарниковых зарослях, ольховниках, ивняках, молодых осинниках, перемежающихся с полянами, отмечены жимолостная серпокрылая моль, пяденица выемчатокрылая, волнянка ивовая, листовертки. На водных растениях развивается огневка кувшинковая.

По сведениям рыбаков и местных жителей, в озере обитает всего 4 вида рыб (обыкновенная щука, плотва, красноперка и речной окунь).

Земноводные представлены 3 видами (серой жабой, травяной и остромордой лягушками). Были отмечены не только взрослые и молодые зимовавшие особи, но и сеголетки всех трех видов. В лесах по берегам озера обычны серая жаба и травяная лягушка. Благоприятные условия в окрестностях озера Таковец создаются наличием заболоченных участков, развитым травяным покровом и подлеском в лесах, что важно для нерестовых миграций серой жабы, размножение которой отмечено на мелководных и наиболее прогреваемых участках озера. Остромордая лягушки малочисленна, отмечена только в сосняке по берегу озера. В озере и его окрестностях не обнаружено зеленых лягушек, что обусловлено особенностями этого небольшого, но глубоководного водоема.
Из пресмыкающихся в окрестностях озера обитают живородящая ящерица, обыкновенный уж и обыкновенная гадюка. Живородящая ящерица обычна в лесах по берегам озера, а в непосредственно примыкающих к озеру участках даже многочисленна (встречаемость на линейном учетном маршруте составляет 8-10 экземпляров на 1 км). Уж отмечается реже, но тоже обычен: за один учет по периметру озера насчитывается в среднем 4 экземпляра (преимущественно у воды и в воде озера). Гадюка выявлена в некотором удалении от озера, в смешанном лесу.

Птицы - самая разнообразная группа позвоночных животных ООПТ. В июле 2019 г. было выявлено 29 видов птиц из 5 отрядов (гусеобразные, курообразные, ржанкообразные, дятлообразные и воробьинообразные). Непосредственно с озером связаны доминирующая здесь речная крачка и более редкие озерная и сизая чайки и кулик-перевозчик. В весенний период местными жителями отмечалась утка кряква.

В участках лиственных лесов обитают поползень обыкновенный, лазоревка, пестрый дятел. К опушкам смешанных лесов приурочены щегол, большая синица, зяблик, пеночка-весничка, зеленая пеночка, садовая камышевка. К разреженным древостоям тяготеют врановые птицы (сойка и ворон). В хвойных лесах обычно встречаются пеночка-теньковка, пестрый дятел, реже - большая синица и малая мухоловка. В сырых участках с преобладанием ели отмечены теньковка, трещотка, клест-еловик. Для участков смешанного леса с обилием елового подроста и валежником характерны рябчик, серая мухоловка, крапивник, черный дятел, для кустарников на границе с разнотравным лугом - серая славка и речной сверчок. Открытые участки берега посещаются белой трясогузкой и сорокой. В период исследований на ООПТ не было выявлено хищных птиц. В целом авифауна типична для небольших облесенных озер Ивановской области [17].

Из млекопитающих на ООПТ были отмечены 4 вида из 2 отрядов. Это крот обыкновенный, бурозубка обыкновенная, рыжая полевка и бобр. По берегам озера обнаружены поселения бобров, были выявлены следы многолетнего длительного обитания этих грызунов. Для оценки характера и степени их влияния на состояние озерных и прибрежных экосистем необходимы целенаправленные многолетние исследования.

Озеро и его берега испытывают значительные антропогенные воздействия, вызванные рекреационными нагрузками. Оно очень живописное, часто используются для отдыха, а также рыбной ловли и охоты жителями Лежневского района, г. Иванова и других регионов. К озеру от д. Таковец проложена хорошая грунтовая дорога, имеется дорога и от д. Аладино, но она заросла. По всем берегам и в окружающих озеро лесах проложены тропы. Наиболее антропогенно нарушенными являются открытый восточный и северо-восточный берега. В июле-августе 2019 г. были зафиксированы 3 большие туристические стоянки, оборудованные столиками, лавочками, навесами, и более 20 пикниковых точек со старыми кострищами, некоторые костры разводятся рыбаками практически у воды. На берегах озера вырыты ямы, присутствуют груды бытового мусора. Отмечены многочисленные повреждения деревьев (вырезанные на стволах надписи, сломанные ветви, прибитые 
доски и др.), туристами стихийно вырубается подлесок и молодые деревья хвойных пород.

О нарушенности растительного покрова свидетельствуют распространение в лесах и на лугах сорно-рудеральных видов, местами формирующих бурьянистые заросли, а также большое число заносных растений. Всего во флоре ООПТ было обнаружено 28 адвентивных видов. На опушках и луговинах встречаются Berteroa incana (L.) DC., Chenopodium album L., Erigeron annuus (L.) Pers., E. canadensis L., Festuca arundinacea Schreb., Galeopsis bifida Boenn., Lactuca serriola L., Matricaria discoidea DC., Lupinus polyphyllus Lindl., Tripleurospermum inodorum (L.) Sch. Bip. и др.). Отмечен факт присутствия агрессивного чужеродного вида - Heracleum sosnowskyi Manden., найденного на опушке леса западного берега озера. По берегам и в подлеске изредка встречаются распространяемые птицами и человеком деревья Amelanchier spicata (Lam.) C. Koch, Aronia mitschurinii A. Skvorts. et Maytulina, Malus domestica Borkh. Пo берегам озера отмечаются небольшие группы Bidens frondosa L., Epilobium adenocaulon Hausskn, E. pseudorubescens A. Skvorts., Juncus tenius Willd., в воде часто встречается Elodea canadensis Michx.

Научный интерес представляет находка на восточном берегу озера редкого адвентивного вида череды сросшейся (Bidens connata Muehl. ex Willd.), которая впервые была обнаружена в Ивановской области в 2014 г. [18]. С помощью анализа нуклеотидных последовательностей ядерного участка ITS было подтверждено гибридогенное происхождение данного вида и отнесение его к таксону Bidens $\times$ decipiens Warnst [19]. Также на песчаных отмелях озера были найдены одиночные экземпляры лесостепного вида кипрея четырехгранного (Epilobium tetragonum L.), который только начинает распространяться в регионе и впервые указан в 2018 г. [20]. Факты быстрого распространения данного вида отмечаются и в соседней Владимирской области $[15 ; 21]$. За состоянием и расселением адвентивных, особенно инвазионных видов, необходим мониторинг.

\section{Заключение}

В результате исследований были подготовлены материалы для составления и утверждения паспорта ООПТ «Озеро Черное, или Таковец». Рекомендуемая площадь ООПТ составляет 17 га, она включает акваторию озера (10,8 га), а также лесные и луговые сообщества по его берегам. Были выделены особо ценные объекты (песчаные отмели озера, популяции редких видов растений, старовозрастные деревья местных лесообразующих пород), разработаны режимы охраны данного объекта. ООПТ важна для сохранения биоразнообразия Лежневского района и Ивановской области в целом. Здесь отмечено высокое разнообразие сосудистых растений, мхов, птиц и насекомых, имеются местообитания редких видов растений, в том числе видов, включенных в региональную Красную книгу. Озеро - ценный гидрологический объект, источник чистой воды, оно имеет большое рекреационное значение, перспективно для развития экологического и событийного туризма. Сохраняется научная и эколого-просветительская роль экосистем озера Таковец, возможно проведение здесь учебных занятий и экскурсий.

\section{Благодарности}

Авторы выражают сердечную благодарность бриологу А.И. Сорокину за определение видов моховидных, а также М.П. Шилову и М.А. Голубевой за совместные исследования в 2011 г.

\section{Список литературы:}

1. Борисова Е.А., Шилов М.П., Курганов А.А. Флора и растительность ООПТ Ивановской области «Озеро Шадрино» // Самарская Лука: проблемы региональной и глобальной экологии. 2017. Т. 26, № 3. С. 87-93.

2. Борисова Е.А., Курганов А.А., Мишагина Д.А. Флора и растительность памятника природы «Озеро и болото Ценское» // Природное наследие России: сб. науч. ст. междунар. науч. конф., посвящ. 100-летию национального заповедного дела и Году экологии в России / под ред. Л.А. Новиковой. Пенза: Изд-во ПГУ, 2017. С. 117-119.

3. Борисова Е.А., Курганов А.А., Голубева М.А., Сорокин А.И., Шилов М.П. Болото Исака - памятник природы Ивановской области // Самарская Лука: проблемы региональной и глобальной экологии. 2019. T. 28, № 1. С. 148-152.

4. Борисова Е.А., Курганов А.А., Марков Д.С. Озеро Белое - особо охраняемая территория Комсомольского района Ивановской области // Известия Самарского научного центра РАН. 2018. Т. 20, № 5-3. C. $417-422$.

5. Борисова Е.А., Курганов А.А., Марков Д.С., Шилов М.П. Озеро Юрцино (Юрцинское) Ивановской области // Проблемы природопользования и экологическая ситуация в Европейской России и на сопредельных территориях: мат-лы VII междунар. науч. конф. памяти проф. А.Н. Петина. Белгород: Пролитера, 2017. С. 395-397.

6. Борисова Е.А., Курганов А.А., Лазарева О.Г. Озеро Пестяковское - памятник природы Ивановской области // Вестник Ивановского государственного университета. Серия: Естественные, общественные науки. 2018. № 2. С. 10-17.

7. Борисова Е.А. Итоги изучения флоры и растительности Ивановской области // Вестник Ивановского государственного университета. Серия: Естественные, общественные науки. 2014. № 2. С. 5-10.

8. Борисова Е.А., Шилов М.П., Марков Д.С., Курганов А.А. Памятник природы Ивановской области «Озеро Заборье»// Известия Самарского научного центра РАН. 2016. Т. 18, № 2. С. 47-50.

9. Шилов М.П. Ценные природные объекты Лежневского района // Краеведческие записки. Вып. Х. Иваново: Иван. гос. ун-т, 2007. С. 339-352.

10. Редкие растения и грибы: материалы по ведению Красной книги Ивановской области / Е.А. Борисова, М.П. Шилов, М.А. Голубева, А.И. Сорокин, Л.Ю. Минеева / под ред. Е.А. Борисовой. Иваново: ПресСто, 2013. 124 с.

11. Маевский П.Ф. Флора средней полосы европейской части России. 11-е изд. М.: Т-во науч. изд. KMK, 2014. 635 c.

12. География почв и почвенное районирование центрального экономического района СССР / под ред. Г.В. Добровольского и И.С. Урусевской. М.: Изд-во Моск. ун-та, 1972. 488 с.

13. Красная книга Ивановской области. Т. 2. Растения и грибы / под ред. В.А. Исаева. Иваново: ПресСто, 2010. 192 с. 
14. Борисова Е.А., Шилов М.П., Курганов А.А. Флора и растительность озера Поныхарь // Научные труды Национального парка «Хвалынский»: материалы II всероссийской научно-практической конференции. Вып. 7. Саратов-Хвалынск: Амирит, 2015. C. $76-80$.

15. Серегин А.П. Флора Владимирской области: Конспект и атлас. Тула: Гриф и К, 2012. 620 с.

16. Сорокин А.И. Дополнения к флоре мхов Ивановской области // Бюллетень МОИП. Отдел биологический. 2015. Т. 120, вып. 3. С. 72-74.

17. Герасимов Ю.Н., Сальников Г.М., Буслаев С.В. Птицы Ивановской области. М.: Типография Россельхозакадемии, 2000. 125 c.
18. Борисова Е.А., Курганов А.А. Новые и редкие виды растений Ивановской области // Ботанический журнал. 2015. Т. 100, № 5. С. 504-507.

19. Галкина М.А., Виноградова Ю.К. К вопросу о гибридогенном происхождении Bidens $\times$ decipiens Warnst // Российский журнал биологических инвазий. 2019. № 3. С. 13-23.

20. Борисова Е.А., Курганов А.А. Сведения о нахождении новых и редких видов в Ивановской области // Бюллетень МОИП. Отдел биологический. 2019. T. 124 , № 3. C. $32-36$.

21. Серегин А.П. Экспансии видов во флору Владимирской области в последнее десятилетие // Ботанический журнал. 2010. Т. 95, № 9. С. 1254-1268.

\section{BIODIVERSITY OF LAKE CHERNOE (TAKOVETS), A SPECIALLY PROTECTED NATURAL AREA IN THE IVANOVO REGION}

Borisova Elena Anatolyevna, doctor of biological sciences, professor, head of General Biology and Physiology Department

Kurganov Anton Aleksandrovich, candidate of biological sciences, associate professor of General Biology and Physiology Department

Lazareva Olga Germanovna, head of Training Laboratory of General Biology and Physiology Department Ivanovo State University (Ivanovo, Russian Federation)

Markov Dmitriy Sergeevich, candidate of geographical sciences, associate professor of History, Geography and Ecology Department Shuya Branch of Ivanovo State University (Shuya, Ivanovo Region, Russian Federation)

Abstract. The paper deals with some questions of specially protected natural areas (SPNA) of the local level Lake Chernoe (Takovets) is located in Lezhnevo municipal District of the Ivanovo Region and it was founded as a SPNA in 1975, in 2001 it became a SPNA of the local level. The area of the lake is 10,8 hectares, the area of the SPNA is 17 hectares. The paper contains data of a complex ecological study: the lake's parameters, the topography of the banks and soil, the features of its flora, vegetation and fauna. 256 vascular plant species from 5 departments, 6 classes, 62 families and 164 genera were registered by 2019. 13 plant species are rare for the Ivanovo Region flora, among them 3 species (Nuphar pumila, Rubus chamaemorus, Rubus nessensis) are included into the Red Data Book; their populations are briefly characterized. The species composition of mosses is diverse (29 species were noted in total). The fauna is typical of small closed region lakes. The lake is pressed by anthropological factors, its ecosystems are disturbed, it promotes invasive alien plants (there are 28 alien plant species). The lake has a great hydrological, scientific and environment-forming value, it is perspective for ecological tourism planning.

Keywords: specially protected natural areas (SPNA); lakes; bathymetric schema; plant communities; flora; populations of rare plant species; alien and invasive plant species; mosses species; features of fauna; Red Data Book; Lezhnevo District; Ivanovo Region.

$$
* * *
$$

\section{ВЛИЯНИЕ АРИДИЗАЦИИ НА ОСОБЕННОСТИ СУБСТРАТНОГО И БИОТОПИЧЕСКОГО РАСПРЕДЕЛЕНИЯ ВИДОВ ГРИБОВ РОДА РОLYPORUS S.L. ЮГО-ВОСТОКА ЗАПАДНОЙ СИБИРИ}

Власенко Вячеслав Александрович, кандидат биологических наук, старший научный сотрудник лаборатории низших растений

Власенко Анастасия Владимировна, кандидат биологических наук, старший научный сотрудник лаборатории низших растений

Центральный сибирский ботанический сад СО РАН (2. Новосибирск, Российская Федерация)

Турмунх Дэжидмаa, $\mathrm{PhD}$, старший научный сотрудник лаборатории патологии растений Научно-исследовательский институт защиты растений Монголии (г. Улан-Батор, Монголия)

Аннотащия. Изучены особенности субстратного и биотопического распределения видов грибов рода Polyporus s.1. юго-востока Западной Сибири. Большинство видов имеют широкий спектр субстратов, представленных различными видами древесных растений. Наиболее широко распространенные и часто встречающиеся виды способны осваивать большой спектр субстратов. Редкие виды отличаются узким субстратным 